MATA KULIAH: Teologi Sistematika II

DOSEN PENGAMPU: Kalis Stevanus, M.Th.

TUGAS RESENSI JURNAL

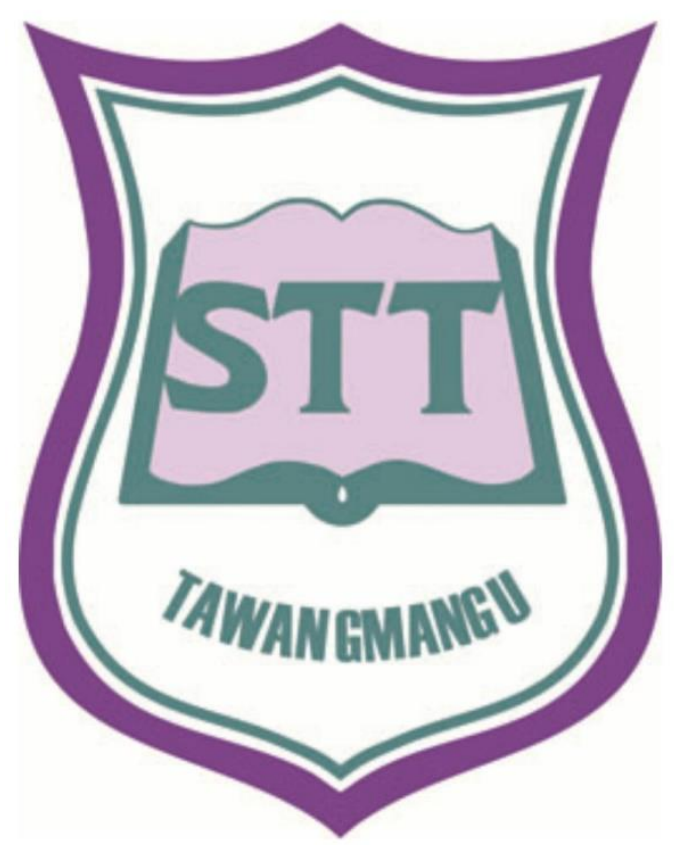

OLEH:

NAMA: Jonathan Hizkia Hosea Salendur

NIM: 396419

SEKOLAH TINGGI TEOLOGI TAWANGMANGU

KARANGANYAR

2020 


\title{
BUKTI KEILAHIAN YESUS MENURUT INJIL ${ }^{1}$
}

Nama Jurnal : : Teruna Bhakti vol. 2 no. 2 Februari 2020

Penulis : Kalis Stevanus

Tahun Terbit $\quad: 2020$

Nama Penerbit $\quad$ : Teruna Bhakti

Halaman $\quad$ : 82-96 (15 halaman)

\begin{abstract}
Abstrak:
Keilahian Yesus merupakan inti dari iman Kristen. Prinsip ini seringkali diragukan oleh banyak kalangan. Tulisan ini bertujuan untuk memegang bukti-bukti yang kuat dan meyakinkan tentang keilahian Yesus menurut pemberitaan keempat Injil; Matius, Markus, Lukas dan Yohanes. Metode penulisan yang digunakan adalah analisis biblikal terhadap ungkapan Yesus sebagai Allah dengan mendasarkan pada teks di dalam keempat Injil. Hasil temuan memperlihatkan ada banyak teks dari keempat Injil yang mengindikasikan keilahian Yesus.
\end{abstract}

Kata kunci: Kristologi; Injil; Yesus; keilahian Yesus.

\section{Resensi}

Kekristenan mengakui bahwa Yesus adalah 'manusia sejati' dan sekaligus 'Allah sejati'. Menurut Wijanto, bahwa hal ini tidak pernah dapat dijelaskan dengan baik dan sulit dan membingungkan banyak orang Kristen. Banyak juga orang nonKristen yang salah mengerti klaim ini sehingga menimbulkan sanggahan-sanggahan. Namun hal ini hanya akan membahas klaim mengenai keallahan Yesus di dalam Injil.

Keilahian Yesus dapat dipertimbangkan melalui bukti-bukti yang terdapat di dalam Alkitab, khususnya di dalam Injil. Menurut F.F. Bruce dan W.J. Martin, kepercayaan pada keilahian Kristus berasal langsung dari pernyataan tentang Dia di

\footnotetext{
${ }^{1}$ Kalis Stevanus, 'Bukti Keilahian Yesus Menurut Injil', Jurnal Teruna Bhakti (2020).
} 
dalam Alkitab, dan klaim kesetaraan Kristus dengan Allah yang didasari oleh pengajaran-Nya sejak awal. Para murid dan orang-orang Yahudi menyadari kesetaraanNya dengan Allah (Yoh. 5:18). Hal ini juga diungkapkan oleh Daniel Doriani bahwa Yesus menyadari keilahian-Nya disepanjang hidup dan pelayanan-Nya. Menurut Suliana Gunawan, momen krusial pengakuan Yesus sebagai Anak Allah adalah pengakuan Petrus kepada Yesus: "Engkau adalah Mesias, Anak Allah yang hidup!" (Mat. 16:16; Mrk. 8:29; Luk. 9:20) dan hal itu diakui oleh Yesus sendiri. Pernayataan Petrus itu berarti Yesus memiliki sifat-sifat yang sama dengan Allah. Markus juga mencatat kisah roh-roh jahat yang menyebut Yesus: "Engkaulah Anak Allah." (Mrk. 3:11). Mark. 14:61-64 menulis peristiwa dimana Yesus secara terang-terangan mengakui atau menyatakan diri-Nya sebagai Mesias, Anak Allah dan Anak Manusia.

Yesus mengakui menyamakan diri-Nya dengan Allah (Yoh. 10:30; 14:9). Melalui hal tersebut, Yesus mengakui kepada banyak orang bahwa Ia adalah Allah. Di dalam Injil Yohanes 8:58, menurut Jonathan A. Draper, bagi Yohanes, Yesus adalah sosok ilahi YHWH yang menampakkan diri kepada Musa (Kel. 34:6). Ungkapan "Aku Adalah Aku" menggunakan frasa ego eimi. Pada zaman Tuhan Yesus, sebutan ini berpadanan dengan sebutan YHWH yang dianggap sakral dan sangat dihormati oleh orang Yahudi. Sebutan ego eimi yang dipakai oleh Allah, dipakai juga oleh Yesus.

Pengakuan Yesus juga tercatat didalam Matius 12:6 yaitu bahwa Yesus melebihi Bait Allah yang merupakan tempat kediaman Allah. Hal ini menyatakan bahwa Yesus adalah Tuhan atas hari Sabat dan Ia adalah pencipta Sabat.

Ada juga bukti-bukti di teks Alkitab yang lain yang mencatat keilahian Yesus, yaitu: Yesus mengklaim memiliki hak untuk dihormati seperti Allah (Yoh. 5:23), Yesus menerima penyembahan seperti Allah (Mat. 8:2), menghakimi umat manusia (Mat. 7:22-23), tidak berdosa (Mat. 27:3-4), mengampuni dosa (Luk. 5:20), memberikan hidup kekal (Yoh. 11:25), nasib kekal manusia bergantung pada respon terhadap Yesus, perkataan-Nya bersifat kekal (Mat. 5:18), mengidentifikasi tindakan terhadap diri-Nya sama dengan tindakan kepada Allah (Yoh. 8:19), menyatakan diri-Nya adalah terang dunia (Yoh. 1:4,5,7,8,9), disebut sebagai Immanuel dan Juruselamat (Mat. 1:23) dan Yesus kekal (Yoh. 1:1-3) dimana menunjukkan bahwa Yesus telah ada sejak permulaan atau kekekalan. 


\section{Kelebihan dan Kekurangan Jurnal}

Kelebihan dari jurnal ini adalah pembahasan mengenai bukti keilahian Yesus dijelaskan dengan detail menggunakan ayat dan disusun secara sistematis dengan bahasa yang mudah dipahami. Bukti-bukti konkret dijelaskan secara rinci sehingga bisa dijadikan pedoman hidup orang percaya masa kini.

Kekurangan dari jurnal ini adalah penulisan kata yang salah dibeberapa teks. Ada beberapa bagian di dalam teks yang agak sulit dipahami karena struktur kalimat yang kurang efektif.

\section{Simpulan dan Rekomendasi}

Kesimpulannya, jurnal ini merupakan jurnal yang sangat baik untuk dipelajari dengan pembahasan yang sederhana dan teruji berdasarkan metode yang diambil. Jurnal ini sangat bermanfaat khususnya bagi kalangan orang Kristen masa dan dan dapat dijadikan bahan apologetik. Jurnal ini dapat diteliti lebih dalam lagi dan dikembangkan dari sisi kemanusiaan Yesus. 